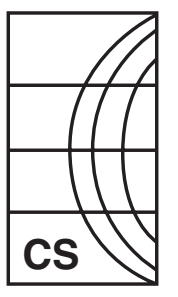

\title{
Childhood in Sociology and Society
}

\section{The US Perspective}

Loretta E. Bass

University of Oklahoma

abstract: The field of childhood studies in the US is comprised of cross-disciplinary researchers who theorize and conduct research on both children and youth. US sociologists who study childhood largely draw on the childhood literature published in English. This article focuses on American sociological contributions, but notes relevant contributions from non-American scholars published in English that have shaped and fueled American research. This article also profiles the institutional support of childhood research in the US, specifically outlining the activities of the 'Children and Youth' Section of the American Sociological Association (ASA), and assesses the contributions of this area of study for sociology as well as the implications for an interdisciplinary field.

keywords: childhood $\downarrow$ children $\downarrow$ children's well-being $\downarrow$ social inequalities social policy $\downarrow$ United States

\section{Introduction}

My approach to providing a US country report on the sociological study of children takes three forms. I first examine the US context of the study of children since 1980, discussing important research findings and the development of the field. Walkerdine (2004) provides a comprehensive discussion of the earlier debate focused on when childhood became distinguished from adulthood - such as Ariès (1962 [1960]), de Mause (1974) and Demos (1970). I then examine the major perspectives and research initiatives as they inform the empirical lives of American children. Finally, I consider the usefulness of childhood as an interdisciplinary area of study, and present a vision for the future of childhood studies within sociology. 


\section{The US Context of Childhood Sociological Research}

American sociology takes a broad definition of childhood studies - or the study of children and youth - to include researchers who theorize and conduct research on children and adolescents. The US context of the study of children can be divided into two main areas, research and teaching, and the larger social and political climate in which both of these are supported. In both of these areas, European sociologists, interacting through the International Sociological Association (ISA) Research Committee 53 on Sociology of Childhood, have made substantial contributions to the development of the childhood studies field. Europeans administer the two major childhood publishing outlets, Childhood and Children and Society. In addition, British childhood scholars have published four textbooks for sociology of childhood classes offered by the Open University: Understanding Childhood by Woodhead and Montgomery (2003), Childhoods in Context by Maybin and Woodhead (2003), Children's Cultural Worlds by Kehily and Swann (2003) and Changing Childhood by Montgomery et al. (2003). American sociologists have also offered substantial contributions (e.g. Corsaro, 1997) but these generally fall within the confines of traditional academic disciplines, such as sociology and psychology.

Scholarly research and teaching on childhood by American sociologists finds a home in the 'Children and Youth' Section of the American Sociological Association (ASA), which was originally the Children's Section from 1992 until 2000. The 'Sociological Studies of Children and Youth' series (Kinney and Rosier, series editors, Elsevier Science), formerly the 'Sociological Studies of Children' until 2000, stands out as the sole American publishing outlet geared to sociologists who study children. Members of the ASA's 'Children and Youth' Section have published this annual research volume since 1986. For monographs focused on childhood and children's issues, two prominent presses include Rutgers University Press, which has a series titled 'Childhood Studies', and Lynne Rienner Press, which has a series on 'Children at Risk'.

In terms of teaching and curriculum development, early development took place in the disciplines of psychology or education. After 1990, though, sociology courses which focus on children and childhood have begun to be offered by American universities and colleges. The ASA publishes the Sociology of Children and Childhood Teaching Resource Guide (editor, Sue Marie Wright, 2003), which offers sample syllabi, assignments and projects for sociology courses focused on children. A few American undergraduate textbooks centered on childhood have been published, including Elkin and Handel's (1988) The Child and Society, Corsaro's (1997) Sociology of Childhood, Boocock and Scott's (2005) Children in Contexts and Handel et al.'s (2007) The Sociology of Children and Childhood Socialization. While the Elkin and Handel, 
Corsaro and Handel et al. texts take a sociological perspective, Boocock and Scott use a more interdisciplinary approach. In terms of curriculum development, Brooklyn College and Eastern Washington University both offer an undergraduate major in Children's Studies, and Brooklyn College also has an interdisciplinary Children's Studies Center. Rutgers University offers certificates at the BA and MA levels in childhood studies, and houses the interdisciplinary Rutgers University Center for Children and Childhood Studies. Therefore, there has been teaching and curriculum development of childhood studies within the discipline of sociology, but this has taken place within a larger context of childhood studies that encompasses the disciplines of sociology, psychology, anthropology and education.

\section{Major Theories and Approaches in American Childhood Research}

Social constructivist approaches, social structural approaches and demographic approaches all are used to interpret the lives of American children. These approaches allow us to know how it is that children actively construct meaning, how they are constrained by social structure and also how our understanding of children's lives can be used to inform public policy and protect children's rights and well-being.

This section discusses each of these in turn.

\section{Social Constructivist Approaches}

American cultural and social constructivist approaches to childhood studies are informed by theoretical work published in Europe and the earlier anthropological work of Opie and Opie (1969), who argued that children should be recognized separately and autonomously from adults as a community with its own stories, rules, rituals and social norms. In the 1970s, American anthropologist Bluebond-Langner (1978) interpreted dying children's worlds using their words and points of view to explain how these children comfort their parents and doctors. More recently, Clark (2003) explains how humor and play interactions initiated by chronically ill children help families cope. In Europe, Qvortrup (1994) presented childhood as a 'social phenomenon'. Likewise, other European sociologists had begun to use social interaction theory to include the daily activities and wishes of children when interpreting their lives (e.g. James and Prout, 1997 [1990]; Jenks, 2004; Maybin and Woodhead, 2003; Qvortrup, 1993; Stainton Rogers et al., 1991; Woodhead, 1999). Corsaro (1988) contributed to American theorizing by interpreting the meaning of children's lives from their social networks. Gathering data on children's everyday experiences and what these experiences mean to children is in agreement with ethnographic methods that use reflexivity and include children's voices. 
Social constructivist research within institutional settings, such as day care centers and schools, finds that young children add meaning to their experiences and create peer cultures. Toddler peer groups have been noted to emerge among two year-olds and they already show preferences for sex and race (Thompson et al., 2001; van Ausdale and Feagin, 2001). Play builds upon itself and across playgroups or peer groups, even when the composition of children's groups change. The children develop shared rules and meanings that define how the play activity proceeds and who is welcome to join the play. These rules and meanings exist at the community level for the children's play, so that the play or game continues even when individuals leave or join the group.

Studies done in institutional settings, such as public schools and day care centers, also allow us to analyze childhood (see Adler and Adler, 1988; Corsaro, 1988; Hardman, 1973; Thorne, 1993; van Ausdale and Feagan, 2001). Corsaro (1988) uses participant-observation research of children in the playground in a nursery school setting in Italy and a kindergarten setting in the US as the basis for explaining children's lives and perspectives. In the same vein as British anthropologist Hardman's (1973) earlier observations within a primary school, Corsaro (1988) examined the level of children's experience as it interacts with other levels of society's beliefs, values and social interactions, shaping them and being shaped by them. In this way, children are presented as active agents who create meaning through social interactions and their relationships. Similarly, Corsaro and Eder (1990) present young children in free play recreating elements of the adult world in their child-level culture. Van Ausdale and Feagan (2001) use participantobservation and the social constructivist approach again to show how young children's play patterns and discourse teach other children about race. Their study, The First R: How Children Learn Race and Racism, finds that not only do children learn how to identify with racial difference, but they also learn that there is a pecking order of privilege and acceptable behavior across different race groups, as well as their relative place in the racial ordering. Adding to this, other studies (Cahill, 1986; Milligan and Brayfield, 2004) explore how adults treat children in public settings and how these interactions provides a framework for give and take, and cultural acquisition and practice.

Patricia Adler and Peter Adler (1988) explain how children create a stratification structure within a middle school setting in Peer Power. With Gender Play, Barrie Thorne (1993) does a similar type of study of gradeschool children. Thorne makes the case that while it is assumed that children's culture is set in an elementary school setting, the children are still active in making the rules and creating social structure. As an example, Thorne explains how children use 'pollution rituals' within the games they create and play to 'enact larger patterns of inequality, by gender, by social class and race, and by bodily characteristics like weight and motor 
coordination' (Thorne, 1993: 75). In this way, she contends that children create a stratification structure that is similar to the adult world as they perceive it. Portraying children as actively creating meaning, Lamb's (2002) research documents how children share and communicate knowledge about sex with their peer group using a secretive child culture. Extending this research, British peer culture studies on racism, masculinity and sexism (see Frosh et al., 2002; Hey, 1997; James et al., 1998) and Ambert's (1995) study of the subjects of physical and emotional abuse among Canadian children provide insight into how these sensitive subjects are taught and negotiated within children's peer groups. Across these studies, children are actively interpreting and creating the meanings that define their culture.

\section{Social Structural Approaches}

Age as social structure, whether measured as younger children vs older children, or by a generational marker of child and adult, is also used to define and understand childhood. As discussed earlier, Thorne (1987) views age and gender as structures that frame children's lives, but she also views children as social agents affecting these structures and creating their own culture within these structures. Bass (2004) similarly finds that primarily age, and then economic status and gender, together constrain opportunities open to children who work in an open air market in sub-Saharan Africa. At the same time, children remain active contesters and participants of their work worlds. Passuth's (1987) research finds that age is more salient than other stratification markers, such as race, social class and gender. Passuth finds that children of five to 10 years old in a summer camp setting sort and define themselves as little and big kids. Other research (Goodwin, 1990; Scott, 2002) suggests again that age should be considered conjointly with race, gender and social class to understand how power and prestige are negotiated within children's peer cultures.

Viewing age more broadly, Foner's (1978) life course work provides valuable early insight into age, and more specifically, generational status, as an analytic tool to understand a generation's outlook on relationships and family formation. According to Foner (1978: 343), 'Each cohort bears the stamp of the historical context through which it flows [so that] no two cohorts age in exactly the same way.' Foner explains that those of each cohort may develop similar attitudes because they have experienced the same larger social and political milieu. More recently, age continues to be useful as a prominent marker as European and Canadian scholars find generational status to be a main factor defining children's lives (e.g. Alanen, 2001; Mayall, 2000; Qvortrup, 2000; Walkerdine, 2004).

Putting forth a structural thesis, Zelizer (1994) explains how the modern child emerged from economically 'useless' in the late 1800s to emotionally 
'priceless' in the 1930s. She argues that an economic view of life is limited because it fails to include important social, cultural, emotional and moral factors in the marketplace (e.g. children's life insurance policy values). In his social history of the children's clothing industry in the US, The Commodification of Childhood, Dan Cook (2004) explains how childhood became associated with products and contends that childhood became commodified first with the publication of a 1917 trade journal advertising children's clothing, and then by recognizing a legitimate child consumer acting on his/her own needs and wishes by the 1960s. Cook shows how the consuming child today has a separate children's department within clothing stores that is stratified by age and gender, and that this separate children's consumer sphere was constructed during the 20th century. Other research has examined childhood through the lens of their material world (e.g. Cross, 1997; Lamb, 2002; Zelizer, 2002). More recently, Zelizer (2002) defines children as more active, participating and shaping culture as producers, consumers and distributors. Similar to Cook's thesis, research outside the US by childhood scholars similarly shows how children's consumption defines childhood (e.g. Buckingham, 2004; Jing, 2000; Kline, 1993; Postman, 1982) and may even diminish the power differential between children and adults (e.g. see Tapscott's [1998] internet technology study).

Adding to this, Qvortrup (1993) explains that children inhabit and interact with institutions differently from adults, because they hold a child status. The factors framing the social structural child are therefore larger than age status, as they create age status in a childhood process (Qvortrup, 1994). Children are treated differently within the social structure and have certain traits resulting from interaction (as children) with the institutional structure of societies. Generation can, therefore, be viewed as a structural marker that distinguishes experiences, interactions and social meaning. This perspective allows us to understand how the experiences of children within a certain epoch can lead to a change over time in larger social norms and values.

Rather than focusing only on peer influences, Lareau (2002) puts forth a social structural model of socialization as she details how American families of different races and classes provide different childhoods for their children. In her research, different parenting philosophies set within the constraints of parents' different resource levels are used to explain different childhoods by class and race. Lareau focuses on the constraints of race and class, while at the same time recognizing that children and parents construct childhoods in the context of constrained choice. She found evidence of two types of child rearing, concerted cultivation on the part of middle-class parents and the emergence of natural growth on the part of working-class parents, that then put upper- and lower-class children, respectively, on different roads in childhood that translate into vastly different opportunities in adulthood. 


\section{Demographic Approaches}

Childhood studies in the US has been strengthened by the research of demographers who often take a top-down approach to the study of children, viewing them as being interlinked with a larger family structure. Demographic research concerning children has also addressed pressing public policy issues, making meaningful connections between parent's employment, health insurance, family poverty and family stability, on the one hand, and indicators of child well-being, on the other. In the US context, child well-being indicators may include any number of factors, such as being-on-track-grade-for-age or exhibiting confidence or maturity, on the one hand, to the use of cigarettes, alcohol or drugs, and having emotional problems, on the other. The study of children's well-being in the academy has been fueled by government and private foundation grants and fellowships that seek to monitor the lives of children. Additionally, non-governmental policy organizations, such as Child Trends and the Annie E. Casey Foundation, have fueled the study of children's well-being. Indeed, within social demography, a sizable literature has been developed on what leads to positive and negative measures of child well-being.

Using US decennial census data during the 20th century, Hernandez (1993) argues that several 'revolutions' took place in the American family, such as decreased family size and the emergence of two-earner families. These shifts in the family cause subsequent effects on children's well-being and American childhood. Children from small, high-income family backgrounds generally attain more education and take more lucrative employment, compared to children from larger families and lower incomes. The increase in dual-earner families fuels higher income. Currently, roughly 70 percent of preschoolers' mothers work outside the home (US Bureau of the Census, 2002). This movement of women into the labor market caused what Hernandez calls a childcare revolution, changing the nature and structure of American childhood over the past 50 years. In 1940, just 13 percent of preschoolers had two working parents (US Bureau of the Census, 2002). Other studies document children's increased amount of household chores since 1981 (Hofferth and Sandberg, 2001), the impact of maternal employment on time spent with children (Bianchi, 2000; Cooksey et al., 1997) and children's higher propensity than their fathers in dual-earner families to make up the household labor gap left when mothers work outside the home (Lee et al., 2003). The meaning of childhood is therefore altered as a result of larger family considerations and expectations.

Family life affects children's well-being. For example, when marriages break up, children typically experience subsequent transitions that may include living with one parent, moving to a new home or neighborhood, and changing schools and making new friends. Some studies report negative effects, while others more positive effects, when examining children's 
well-being. Research on family structure (Moore et al., 2002) finds that children do better in families with two intact biological parents in a lowconflict marriage. Crowell and Leaper (1994) show that financial support from fathers after a divorce is low, and this serves as a complicating factor in explaining children's well being. Agreeing with this, Coontz (1997) explains that divorce and single parenthood lead to lower financial security. Conversely, other research indicates that children of divorce typically experienced parental conflict and behavioral and educational problems prior to the divorce, so it is difficult to isolate divorce as being the precursor to negative child well-being outcomes (Cherlin et al., 1991). Also, children of divorce report that they are more independent compared with their peers of intact biological parent homes (Smart et al., 2001). Finally, Hetherington (2002) finds that 75 percent of children with divorced parents ranked at the same level on behavioral and educational outcomes as children from intact biological families within six years.

The demographic perspective takes a prominent place in American childhood studies informing family policy. Indicators of child well-being are framed within a changing family context where there are possible consequences for children. The demographic perspective does not fulfill the qualitative requirement put forth by European social constructivist childhood scholars (see James and Prout, 1997 [1990]). Children are accorded little agency, while their well-being remains the focus. In this way, childhood social demographers also provide a valuable perspective to frame and interpret children's lives within American sociology.

\section{Public Discussions of Childhood Studies as an Emergent Discipline}

\section{Interdisciplinary Involvement and Implications}

A range of disciplines currently active in the study of childhood helps us understand children's lives and creates meaningful discourse of the underlying methods and theories, which, in turn, create fresh approaches to the study of children. While developmental psychology laid an early foundation of interest in children, the field of childhood studies has emerged as a discourse across other disciplines, such as sociology and anthropology, which have pushed the field to include a broad range of methods and approaches. The disciplinary make-up of the Center for Children and Childhood Studies at Rutgers University provides a telling example of the breadth of research acceptable for the field: associated scholars hail from sociology, anthropology, psychology, history, library science and religious studies. It is clear that childhood scholars have a great deal to gain from continued conversation and collaboration. 
British sociologist Martin Woodhead (2003) offers three models for children and childhood studies to emerge as an interdisciplinary effort. First, he offers a clearinghouse model that would include all disciplines and all studies of children as having complementary value. Second, he proposes a pick' $n$ ' mix model, where only specific child-centered approaches would be included in the field. Therefore, if some specification is not meant, such as an acceptable method (e.g. the demographic approach not fulfilling the qualitative requirement put forth by European social constructivist childhood scholars, James and Prout, in 1990), then those studies would not be acknowledged as childhood studies. The third model, a rebranding model, would allow that researchers collaborate across disciplines on child-centered research, but remain within a traditional discipline such as sociology, anthropology, or psychology. The third scenario is most common in American sociology today.

Prominent childhood scholars contend that the study of children as a field can be compared to women's studies. Myra Bluebond-Langner (2000) contends that childhood studies will have a similar impact on academic life in the 21st century as women's studies programs have had in the 20th century. Likewise, Oakley (1994: 13) asserts, 'Women and children are, of course, linked socially, but the development of these specialist academic studies also poses interesting methodological and political questions about the relationship between the status of women and children as social minority groups and their constitution as objects of the academic gaze.' Much like women's studies, childhood studies can gain ground in the 21st century as a recognized interdisciplinary field which is supported by childhood studies programs in academic institutions.

\section{Considering the Discipline of Sociology and Childhood Studies}

Using sociological theories and methods, sociologists make unique contributions to the study of children compared with other disciplines. In the US, the sociological study of childhood has gained considerable momentum since the early 1990s when courses, degree programs and research centers began to be established. Originally established as the 'Sociology of Children' Section in the ASA in 1992, members later agreed to add 'and Youth' to the name to include those scholars who examine adolescents. Similarly, the editorial board of the Section's annual series, 'Sociological Studies of Children' (Kinney and Rosier, series editors, Elsevier Science), modified its title to include 'and Youth' in 2000 to reflect the ASA Section title. The Section has affirmed openness to all methods and theories that focus on children, and maintains a listserv, a newsletter and regular presentation sessions at the ASA annual meeting. 
While childhood studies remains interdisciplinary in the US context, sociologists are making substantial contributions. The relationship between the discipline of sociology and childhood studies appears to be symbiotic. Even as sociologists assert that childhood studies is a field of its own (Boocock and Scott, 2005), this does not preclude the development of childhood studies across disciplinary boundaries. Sociologists capture the social position or status of children and have the methods to examine how childhood is socially constructed or situated within a given society. Sociologists can also continue to find common ground with childhood scholars from other disciplines in order to develop better methods and refine theories that explain children's lives. Advances in the interdisciplinary field of childhood studies serves to strengthen the research of sociologists who focus their work on children. Likewise, sociological challenges to the interdisciplinary field of childhood studies since the 1990s have provided useful points of critique and improvement to the study of children's behavior and children's lives.

\section{Current and Future Research - Social Policy and Children's Rights}

Current and future research on children can be loosely grouped into two main areas, social policy and children's rights, with some overlap between the two areas. Sound social policy can improve children's lives. Using public policies to pull children out of poverty provides one example. Hernandez (1993) examined poverty in relation to child well-being indicators, and found that poverty fundamentally provides different opportunities for children, some with relative affluence, to others with relative poverty. One study (Costello et al., 2003), which assessed the effect of increased income after a casino opened on a Cherokee reservation, found that Native-American children who had experienced enough increase to be lifted out of poverty had a lower incidence of behavior disorders. Research has also documented the difficulty in isolating the impact of a policy, such as the 1996 Welfare Reform Law (or PRWORA), on children's lives and childhoods (Bass and Mosley, 2001; Casper and Bianchi, 2002). Another public policy example is that the government's recognition of a family form while ignoring others, such as same-sex parent families, affects the children within those families, because the government may fail to address the needs of children within these ignored family forms (Clarke, 1996). Studying children's lives in different family forms provides public policy insight.

Research on children's rights can involve protecting children (generally from an adult perspective) or guaranteeing children civil rights (such as a legal voice or a vote in elections). Protecting children generally posits that 
children are immature, so legal protection should be accorded to keep children safe from harm and offer them developmental opportunities. With the civil rights approach, children should be allowed to participate in decisions that affect them (Lansdown, 1994; Saporiti et al., 2005). A complex issue like child labor allows us to view the overlap between the two, as children may be viewed as having the right to learn and develop, while at the same time children may be viewed as having the right to provide for themselves (see Bass, 2004; Nieuwenhuys, 1994).

As children are involved as study subjects, new approaches assert the need to include children's voices and input in the research process (Bass, 2005; Leonard, 2005). As adults, childhood scholars are therefore not on an equal footing with children (Fine and Sandstrom, 1988), so there is still work to be done to create methods that adequately involve children as participants in social research. Future research should build on these findings, and continue to view children actively, even if constrained. Focusing on practical children's issues and using empirical research projects will ground and increase our knowledge of the nature of childhood. Much like the last 15 years of American childhood research, future childhood researchers should continue to bridge disciplines and even continents as they find common ground and forge ahead to build institutions that improve the study of children and childhood.

\section{Note}

This article grew out of a formal paper presentation to the International Sociological Association Research Committee 53 on Children (conference titled 'Marginality and Voice: Childhood in Sociology and Society', Wuppertal, Germany, 23-25 June 2005), and from a chapter ('Sociology of Children and Youth') prepared for Clifton Bryant and Dennis Peck, The Handbook of 21st Century Sociology (Sage, 1996).

\section{Appendix}

\section{Book Series}

'Childhood Studies', Rutgers University Press.

'Children at Risk', Lynne Rienner Publishers.

'Sociological Studies of Children and Youth', Elsevier Science.

\section{Journals}

Children, Youth, and Environments, at: www.colorado.edu/journals/cye/

\section{Study Programs}

Brooklyn College Children's Studies Program and Center. 
Eastern Washington University Children's Studies Program.

Rutgers Center for Children and Childhood Studies.

\section{Scientific Associations}

'Children and Youth' Section, American Sociological Association.

\section{Financing}

William T. Grant Foundation.

Spencer Foundation.

National Institutes of Health.

\section{References}

Adler, Peter and Adler, Patricia (1988) Peer Power: Preadolescent Culture and Identity. New Brunswick, NJ: Rutgers University Press.

Alanen, Leena (2001) 'Explorations in Generational Analysis', in Leena Alanen and Berry Mayall (eds) Conceptualizing Child-Adult Relations, pp. 11-22. London and New York: Routledge/Falmer.

Ambert, Anne-Marie (1995) 'Toward a Theory of Peer Abuse', Sociological Studies of Children 7: 177-205.

Ariès, Philippe (1962) Centuries of Childhood: A Social History of Family Life, trans. R. Baldick. New York: Vintage Books. (Orig. pub. 1960.)

Bass, Loretta E. (2004) Child Labor in Sub-Saharan Africa. Boulder, CO: Lynne Rienner.

Bass, Loretta E. (ed.) (2005) Sociological Studies of Children and Youth, Vol. 10. Special International Volume. London and New York: Elsevier Science.

Bass, Loretta E. and Mosley, Jane (2001) 'Assessing the Impact of the 1996 Welfare Reform Legislation on Children's SSI Receipt', Joint Center for Poverty Research Working Paper Series, University of Chicago/Northwestern University.

Bianchi, Suzanne M. (2000) 'Maternal Employment and Time with Children: Dramatic Change or Surprising Continuity?', Demography 37(4): 401-14.

Bluebond-Langner, Myra (1978) The Private Worlds of Dying Children. Princeton, NJ: Princeton University Press.

Bluebond-Langner, Myra (2000) 'Opening Remarks', public opening reception, Center for Children and Childhood Studies, Rutgers University, Camden, NJ.

Boocock, Serane S. and Scott, Kimberly A. (2005) Kids in Context: The Sociological Study of Children and Childhoods. Lanham, MD: Rowman and Littlefield.

Buckingham, David (2004) 'New Media, New Childhoods? Children's Changing Cultural Environment in the Age of Digital Technology', in Mary Jane Kehily (ed.) An Introduction to Childhood Studies, pp. 108-22. Maidenhead and New York: Open University Press.

Cahill, Spencer E. (1986) ‘Childhood Socialization as a Recruitment Process: Some Lessons from the Study of Gender Development', Sociological Studies of Child Development 1: 163-86.

Casper, Lynne and Bianchi, Suzanne (2002) Continuity and Change in the American Family. Thousand Oaks, CA: Sage. 
Cherlin, Andrew, Furstenberg, Frank, Chase-Lansdale, Lindsey, Kiernan, Kathleen E., Robins, Philip K., Morrison, Donna R. and Teitler, Julien O. (1991) 'Longitudinal Studies of Effects of Divorce on Children in Great Britain and the United States', Science 252: 1386-9.

Clark, Cindy Dell (2003) In Sickness and in Play. New Brunswick, NJ: Rutgers University Press.

Clarke, Lynda (1996) 'Demographic Change and the Family Situation of Children', in Julia Brannen and Margaret O'Brien (eds) Children in Families: Research and Policy, pp. 66-83. London: Falmer Press.

Cook, Dan (2004) The Commodification of Childhood. Durham, NC: Duke University Press.

Cooksey, Elizabeth C., Menaghan, Elizabeth and Jekielek, Susan M. (1997) 'Life Course Effects of Work and Family Circumstances on Children', Social Forces 76 (2): 637-66.

Coontz, Stephanie (1997) The Way We Really Are: Coming to Terms with America's Changing Families. New York: Basic Books.

Corsaro, William (1988) 'Routines in the Peer Culture of American and Italian Nursery School Children', Sociology of Education 61: 1-14.

Corsaro, William (1997) Sociology of Childhood. Thousand Oaks, CA: Sage Publications.

Corsaro, William and Eder, Donna (1990) 'Children's Peer Cultures', Annual Review of Sociology 16: 197-200.

Costello, E. Jane, Compton, Scott N., Keeler, Gordon and Angold, Adrian (2003) 'Relationships between Poverty and Psychopathology', Journal of the American Medical Association 2990: 2023-9.

Cross, Gary (1997) Kids' Stuff: Toys and the Changing World of American Childhood. Cambridge, MA: Harvard University Press.

Crowell, Nancy A. and Leaper, Ethel M. (1994) America's Fathers and Public Policy: Report of a Workshop. Washington, DC: National Academy Press.

De Mause, Lloyd (1974) The History of Childhood. Northvale, NJ: John Aronson.

Demos, John (1970) A Little Commonwealth: Family Life in Plymouth Colony. New York: Oxford University Press.

Elkin, Frederick and Handel, Gerald (1988) The Child and Society: The Process of Socialization. New York: McGraw-Hill.

Fine, Gary Alan and Sandstrom, Kent L. (1988) Knowing Children: Participant Observation with Minors. Newbury Park, CA: Sage.

Foner, A. (1978) 'Age Stratification and the Changing Family', in John Demos and Serane Spence Boocock (eds) Turning Points: Historical and Sociological Essays on the Family, pp. 340-65. Chicago, IL: University of Chicago Press.

Frosh, Stephen, Phoenix, Ann and Pattman, Rob (2002) Young Masculinities: Understanding Boys in Contemporary Society. London: Palgrave.

Goodwin, Marjorie H. (1990) He-Said-She-Said. Bloomington: Indiana University Press.

Handel, Gerald, Cahill, Spencer and Elkin Frederick, (2007) The Sociology of Children and Childhood Socialization. Oxford: Oxford University Press.

Hardman, Charlotte (1973) 'Can There Be an Anthropology of Children?', Journal of Anthropological Society of Oxford 4(1): 85-99. 
Hernandez, Donald J. (1993) America's Children: Resources from Family, Government, and the Economy. New York: Russell Sage Foundation.

Hetherington, E. Mavis (2002) For Better or for Worse: Divorce Reconsidered. New York: W. W. Norton.

Hey, Valerie (1997) The Company She Keeps: An Ethnography of Girls' Friendships. Buckingham: Open University Press.

Hofferth, Sandra L. and Sandberg, John F. (2001) 'Changes in American Children's Time, 1981-1997', in Sandra L. Hofferth and Timothy J. Owens (eds) Children at the Millennium: Where Have We Come From, Where Are We Going?, pp. 193-229. Oxford: Elsevier Science.

James, Alison and Prout, Alan (1997) Constructing and Reconstructing Childhood, 2nd edn. London: Falmer. (Orig. pub. 1990.)

James, Alison, Jenks, Chris and Prout, Alan (1998) Theorizing Childhood. Cambridge: Polity Press.

Jenks, Chris (2004) 'Constructing Childhood Sociologically', in Mary Jane Kehily (ed.) An Introduction to Childhood Studies, pp. 77-95. Maidenhead and New York: Open University Press.

Jing, Jun (2000) Feeding China's Little Emperors: Food, Children and Social Change. Stanford, CA: Stanford University Press.

Kehily, Mary Jane and Swann, Joan (2003) Children's Cultural Worlds. Childhood, Vol. 3. Chichester: Wiley/Open University.

Kline, Stephen (1993) Out of the Garden: Toys and Children's Culture in the Age of TV Marketing. London: Verso.

Lamb, Sharon (2002) The Secret Lives of Girls. New York: Free Press.

Lansdown, Gerison (1994) 'Children's Rights', in Berry Mayall (ed.) Children's Childhoods: Observed and Experienced, pp. 33-44. London and Washington, DC: Falmer Press.

Lareau, Annette (2002) Unequal Childhoods: Class, Race, and Family Life. Berkeley, CA: University of Chicago Press.

Lee, Yun-Suk, Schneider, Barbara and Waite, Linda (2003) ‘Children and Housework: Some Unanswered Questions', Sociological Studies of Children and Youth, Vol. 9, pp. 105-25. London and New York: Elsevier Science

Leonard, Madeleine (2005) 'Involving Children in Social Policy: A Case Study from Northern Ireland', pp. 153-69 in Loretta E. Bass (ed.) Sociological Studies of Children and Youth, Vol. 10. Special International Volume. London and New York: Elsevier Science.

Mayall, Berry (2000) 'Conversations with Children: Working with Generational Issues', in Pia Christensen and Alison James (eds) Research with Children: Perspectives and Practices, pp. 120-35. London and New York: Falmer Press.

Maybin, Janet and Woodhead, Martin (eds) (2003) Childhoods in Context. Childhood, Vol. 2. Chichester: Wiley/Open University.

Milligan, Melinda J. and Brayfield, April (2004) 'Museums and Childhood: Negotiating Organizational Lessons', Childhood 11(3): 275-301.

Montgomery, Heather, Burr, Rachel and Woodhead, Martin (eds) (2003) Changing Childhoods: Local and Global. Childhood, Vol. 4. Chichester: Wiley/Open University. 
Moore, Kristin, Jekielek, Susan and Emig, Carol (2002) 'Marriage from a Child's Perspective: How Does Family Structure Affect Children, and What Can We Do About It?', Child Trends Research Brief, June, pp. 1-8.

Nieuwenhuys, Olga (1994) Children's Lifeworlds: Gender, Welfare and Labour in the Developing World. London: Routledge.

Oakley, Ann (1994) 'Women and Children First and Last: Parallels and Differences between Children's and Women's Studies', in Berry Mayall (ed.) Children's Childhoods: Observed and Experienced, pp. 13-32. London and Washington, DC: Falmer Press.

Opie, Iona and Opie, Peter (1969) Children's Games in Street and Playground. Oxford: Oxford University Press.

Passuth, Patricia M. (1987) 'Age Hierarchies within Children's Groups', Sociological Studies of Child Development 2: 185-203.

Postman, Neil (1982) The Disappearance of Childhood. New York: Delacorte Press.

Qvortrup, Jens (1993) Childhood as a Social Phenomenon: Lessons from an International Project, Eurosocial Report 47. Vienna: European Centre.

Qvortrup, Jens (1994) Childhood Matters. Aldershot: Avebury.

Qvortrup, Jens (2000) 'A Generational Approach to a Sociology of Childhood', paper presented at the annual meeting of the American Sociological Association. Washington, DC.

Saporiti, Angelo, Casas, Ferran, Grignoli, Daniela, Macini, Anonio, Ferrucci, Fabio, Rago, Marina, Alsinet, Carles, Figure, Cristina, Gonzalez, Monica, Guso, Mireia, Rostan, Carles and Saturni, Marta (2005) 'Children's Views on Children's Rights', in Loretta E. Bass (ed.) Sociological Studies of Children and Youth, Vol. 10. Special International Volume, pp. 125-152. London and New York: Elsevier Science.

Scott, Kimberly A. (2002) 'You Want To Be a Girl and Not My Friend? AfricanAmerican Girls' Play Activities with and without Boys.' Childhood 9(4): 397-414.

Smart, Carol, Neale, Bren and Wade, Amanda (2001) The Changing Experience of Childhood: Families and Divorce. Cambridge: Polity Press.

Stainton Rogers, Wendy, Hevey, Denise, Roche, Jeremy and Ash, Elizabeth (1991) Child Abuse and Neglect: Facing the Challenge. London: Batsford and the Open University.

Tapscott, Don (1998) Growing Up Digital: The Rise of the Net Generation. New York: McGraw-Hill.

Thompson, Michael, Grace, Catherine and Cohen, Lawrence (2001) Best Friends, Worst Enemies: Understanding the Social Lives of Children. New York: Ballantine Books.

Thorne, Barrie (1987) 'Revisioning Women and Social Change: Where are the Children?', Gender and Society 1(1): 85-109.

Thorne, Barrie (1993) Gender Play. New Brunswick, NJ: Rutgers University Press.

US Bureau of the Census (2002) Who's Minding the Kids? 1997 SIPP Report. Washington, DC: US Bureau of the Census.

Van Ausdale, D. and Feagin, Joe (2001) The First R: How Children Learn Race and Racism. Lanham, MD: Rowman and Littlefield. 
Walkerdine, Valerie (2004) 'Developmental Psychology and the Study of Children', in Mary Jane Kehily (ed.) An Introduction to Childhood Studies, pp. 96-107. Maidenhead and New York: Open University Press.

Woodhead, Martin (1999) 'Reconstructing Developmental Psychology: Some First Steps', Children and Society 13(1): 3-19.

Woodhead, Martin (2003) 'Childhood Studies: Past, Present and Future', keynote lecture at the Open University conference 'Childhood Reconsidered', Open University, Faculty of Education and Language Studies, Oxford, June.

Woodhead, Martin and Montgomery, Heather (eds) (2003) Understanding Childhood. Childhood, Vol. 1. Chichester: Wiley/Open University.

Wright, Sue Marie (ed.) (2003) Sociology of Children and Childhood, 2nd edn. Washington, DC: American Sociological Association.

Zelizer, Viviana (1994) Pricing the Priceless Child. New York: Basic Books.

Zelizer, Viviana (2002) 'Kids and Commerce', Childhood 9(4): 375-396.

Biographical Note: Loretta E. Bass, Associate Professor of Sociology at the University of Oklahoma, focuses her research on children and stratification issues, and has completed research in West Africa, the US and France. Her current work focuses on two areas: (1) a manuscript examining African immigrant children and their mothers in France; and (2) the relationship between health insurance and child well-being in the US. Her book Child Labor in Sub-Saharan Africa (Lynne Rienner, 2004) offers a window on the lives of Africa's child workers drawing on research and demographic data from 43 countries. She served as the guest editor for a special international volume of the monograph series, 'Sociological Studies of Children and Youth' (Elsevier, 2005). Dr Bass has also published many peer-reviewed papers about demographic and stratification issues affecting the lives of children, women and families.

Address: Department of Sociology, University of Oklahoma, 780 Van Vleet Oval, 331 KH, Norman, OK 73019, USA. [email: Lbass@ou.edu] 